\title{
PEMBELAJARAN MATEMATIKA REALISTIK DENGAN METODE PENEMUAN BERBANTUAN INTERACTIVE MULTIMEDIA DITINJAU DARI RESPON BELAJAR
}

\author{
Henry Suryo Bintoro \\ Pendidikan Matematika FKIP Universitas Muria Kudus \\ e-mail: henry.suryo@umk.ac.id
}

\begin{abstract}
The purpose of this study was to determine: (1) whether the learning of mathematics realistic discovery methods aided interactive multimedia produce learning achievement better than conventional learning, (2) whether there is influence students' response to mathematics achievement, (3) whether there is an interaction between learning mathematics with students 'response to students' mathematics achievement. This study uses a quasi-experimental research methods. The population in this study were all fifth grade students of the second semester of the Holy Hadipolo village primary school year 2016/2017, while samples were selected by cluster random sampling is SD 3 Hadipolo as an experimental group with a total of 25 students and SD 2 Hadipolo as a control group by number 25 students. The results showed (1) there are differences in the effect of teaching methods to mathematics achievement, (2) there are differences in mathematics achievement among students with the response study of high, medium, and low., (3) there are differences in the achievement of each learning method consistent at each level of learning responses and differences in learning achievement of each level of learning consistent response to each method of learning.
\end{abstract}

Keywords : Realistic Mathematics; Discovery Methods; Interactive Multimedia; Response Students

Abstrak : Tujuan penelitian ini adalah untuk mengetahui: (1) apakah pembelajaran matematika realistik dengan metode penemuan berbantuan interactive multimedia menghasilkan prestasi belajar yang lebih baik daripada pembelajaran konvensional, (2) apakah terdapat pengaruh respon siswa terhadap prestasi belajar matematika, (3) apakah terdapat interaksi antara pembelajaran matematika dengan respon siswa terhadap prestasi belajar matematika siswa. Penelitian ini menggunakan metode penelitian eksperimental semu. Populasi pada penelitian ini adalah seluruh siswa kelas V semester II SD di desa Hadipolo Kudus tahun pelajaran 2016/2017, sedangkan sampel yang dipilih secara cluster random sampling adalah SD 3 Hadipolo sebagai kelompok eksperimen dengan jumlah 25 siswa dan SD 2 Hadipolo sebagai kelompok kontrol dengan jumlah 25 siswa. Hasil penelitian menunjukkan (1) terdapat perbedaan pengaruh metode pembelajaran terhadap prestasi belajar matematika, (2) terdapat perbedaan prestasi belajar matematika antara siswa dengan respon belajar tinggi, sedang, dan rendah., (3) terdapat perbedaan prestasi dari masing-masing metode pembelajaran konsisten pada masing-masing tingkat respon belajar dan adanya perbedaan prestasi belajar dari masing-masing tingkat respon belajar konsisten pada masing-masing metode pembelajaran.

Kata kunci: Matematika Realistik; Metode Penemuan; Interactive Multimedia; Respon Siswa

\section{PENDAHULUAN}

Kenyataan di lapangan masih banyak guru melakukan pembelajaran konvensional sehingga siswa kurang terlibat secara aktif. Hal ini tidak sejalan dengan Kurikulum saat ini yang antara lain menyebutkan bahwa dalam pelaksanaan kegiatan pembelajaran, guru hendaknya memilih dan menggunakan strategi yang melibatkan siswa aktif dalam belajar baik secara mental, fisik, maupun sosial. Pengajaran dimulai dari hal-hal konkrit dilanjutkan ke hal abstrak.

Berkaitan dengan uraian di atas, maka perlu dipikirkan strategi atau cara 
penyajian dan suasana pembelajaran matematika yang membuat siswa terlibat aktif dan merasa senang dalam belajar matematika. Soedjadi menyarankan untuk memilih suatu strategi yang dapat mengaktifkan siswa dalam belajar. Strategi tersebut bertumpu pada dua hal, yaitu optimalisasi keikutsertaan seluruh indera, emosi, karsa, karya dan nalar. Salah satu upaya yang perlu dilakukan adalah lebih mengakrabkan matematika dengan lingkungan anak. Oleh karena itu dalam pembelajaran matematika, keterkaitan konsep-konsep matematika dengan pengalaman anak dalam kehidupan seharihari perlu dilakukan.

Salah satu pembelajaran matematika yang berorientasi pada penerapan matematika dalam kehidupan sehari-hari adalah pembelajaran matematika realistik. Pembelajaran yang dikembangkan dan diteliti di Belanda selama kurang lebih 38 tahun dikenal sebagai Pendidikan Matemtika Realistik menunjukkan hasil yang sangat menggembirakan.

Respon dapat diartikan sebagai tanggapan seseorang terhadap pengaruh atau reaksi dari luar sehingga mempengaruhi sikap dan tingkah laku. Respon siswa terhadap proses pembelajaran merupakan tanggapan siswa selama mengikuti proses pembelajaran, sehingga mempengaruhi sikap dan tingkah laku siswa dan dapat diungkapkan ke dalam bentuk pernyataan dari siswa tersebut. Dalam hal pembelajaran dengan pendekatan realistik siswa dalam mengikuti proses pembelajaran akan banyak dihadapkan pada komponen-komponen pembelajaran, sehingga sangat dimungkinkan bahwa prestasi belajar dipengaruhi oleh respon siswa terhadap proses pembelajaran.
Tujuan dari penelitian ini adalah (1) untuk mengetahui bagaimana pembelajaran matematika realistik dengan metode penemuan berbantuan interactive multimedia menghasilkan prestasi belajar yang lebih baik daripada pembelajaran konvensional, (2) untuk mengetahui bagaimana pengaruh respon siswa terhadap prestasi belajar matematika, (3) untuk mengetahui bagaimana interaksi antara pembelajaran matematika dengan respon siswa terhadap prestasi belajar matematika siswa.

\section{METODE}

Tempat Penelitian ini adalah SD 3 Hadipolo Kudus, dengan subyek penelitian adalah siswa kelas V semester I tahun pelajaran 2016/2017. Waktu penelitian dimulai pada bulan Juli 2016 sampai bulan Desember 2016.

Metode penelitian yang digunakan dalam penelitian ini adalah metode eksperimen semu (quasi-experimental research). Hal ini dikarenakan peneliti tidak memungkinkan untuk mengendalikan dan memanipulasi semua variabel yang relevan. Seperti yang dikemukakan Budiyono (2003: 82-83) bahwa, “Tujuan penelitian eksperimental semu adalah untuk memperoleh informasi yang merupakan perkiraan bagi informasi yang dapat diperoleh dengan eksperimen yang sebenarnya dalam keadaan yang tidak memungkinkan untuk mengontrol dan atau memanipulasikan semua variabel yang relevan".

Pada penelitian ini yang dilakukan adalah membandingkan prestasi belajar matematika dari kelompok eksperimen yang menggunakan pembelajaran matematika realistik dengan metode penemuan berbantuan interactive 
multimedia dengan kelompok kontrol yang menggunakan pembelajaran konvensioanal. Variabel bebas lain yang mungkin ikut mempengaruhi variabel terikat yaitu respon siswa.

Suharsimi Arikunto (2002: 115) menyatakan bahwa "Populasi adalah keseluruhan subyek yang akan diteliti". Populasi dalam penelitian ini adalah seluruh SD Hadipolo Kudus kelas V semester I tahun pelajaran 2016/2017 yang berjumlah 7 SD, yaitu SD 1 sampai dengan SD 7 dengan proporsi banyak siswa dalam setiap kelas yang seimbang.

Suharsimi Arikunto (2002: 115) mengemukakan bahwa, "Sampel adalah sebagian atau wakil populasi yang diteliti". Sampel dari penelitian ini adalah dua dari tujuh SD yang ada di Desa Hadipolo Kudus tahun pelajaran 2016/2017. Sampel yang diambil dalam penelitian ini digunakan untuk melakukan generalisasi terhadap seluruh populasi yang ada. Dua kelas yang diperoleh dibagi menjadi kelas eksperimen dan kelas kontrol.

Pengambilan sampel dilakukan dengan cara cluster random sampling. Menurut Budiyono (2003: 37) cluster random sampling adalah sampling random yang dikenakan terhadap unit-unit atau subsub populasi. Populasi dari cluster random sampling ini adalah seluruh siswa kelas $\mathrm{V}$ semester I SD di desa Hadipolo Kudus tahun pelajaran 2016/2017. Unit-unit atau sub-sub populasi penelitian ini adalah kelas SD 1 Hadipolo, SD 2 Hadipolo, SD 3 Hadipolo, SD 4 Hadipolo, SD 5 Hadipolo, SD 6 Hadipolo dan SD 7 Hadipolo. Untuk menentukan sampel penelitian dari unit-unit ini dilakukan dengan cara mengundi 2 unit yang akan dijadikan sebagai sampel dari 7 unit yang ada. Undian tersebut dilaksanakan dalam satu tahap dengan dua kali pengambilan. Kelas yang keluar pertama sebagai kelompok eksperimen dan kelas yang keluar berikutnya sebagai kelompok kontrol. Setelah dilakukan pengambilan secara random sampling, terpilih SD 3 Hadipolo untuk kelas eksperimen dan SD 2 Hadipolo untuk kelas kontrol.

Penelitian ini menggunakan rancangan faktorial 2 × 3 dengan maksud untuk mengetahui pengaruh dua variabel bebas terhadap variabel terikat. Tabel rancangan penelitiannya adalah sebagai berikut:

Tabel 1 Tabel Rancangan Penelitian

\begin{tabular}{lccc}
\hline \multirow{2}{*}{$\begin{array}{l}\text { Pembelajaran } \\
\text { matematika }\left(\mathrm{a}_{i}\right)\end{array}$} & $\begin{array}{c}\text { Tinggi } \\
\left(\mathrm{b}_{1}\right)\end{array}$ & $\begin{array}{c}\text { Sedang } \\
\left(\mathrm{b}_{2}\right)\end{array}$ & $\begin{array}{c}\text { Rendah } \\
\left(\mathrm{b}_{3}\right)\end{array}$ \\
\cline { 2 - 4 } & & & \\
$\begin{array}{l}\text { Pembelajaran } \\
\text { Matematika }\end{array}$ & & & \\
$\begin{array}{l}\text { Realistik dengan } \\
\text { metode penemuan } \\
\text { berbantuan } \\
\text { interactive }\end{array}$ & $\mathrm{ab}_{11}$ & $\mathrm{ab}_{12}$ & $\mathrm{ab}_{13}$ \\
$\begin{array}{l}\text { multimedia }\left(\mathrm{a}_{1}\right) \\
\text { Pembelajaran }\end{array}$ & & & \\
Konvensional $\left(\mathrm{a}_{2}\right)$ & $\mathrm{ab}_{21}$ & $\mathrm{ab}_{22}$ & $\mathrm{ab}_{23}$ \\
\hline
\end{tabular}

Metode pengumpulan data yang digunakan dalam penelitian ini adalah sebagai berikut metode dokumentasi, metode angket, dan metode Tes. Dalam penelitian ini analisa data yang digunakan adalah analisis variansi dua jalan $2 \times 3$. Dua faktor yang digunakan untuk menguji signifikansi perbedaan efek baris, efek kolom, serta kombinasi efek baris dan efek kolom terhadap prestasi belajar adalah faktor A (Pembelajaran matematika) dan faktor B (Respon siswa). Teknik analisa data ini digunakan untuk menguji ketiga hipotesis yang telah dikemukakan di depan.

Selain analisis variansi, digunakan pula analisis data yang lain, yaitu uji-Z, metode Lilliefors, dan metode Bartlett. Uji- 
$\mathrm{Z}$ digunakan untuk menguji keseimbangan antara kelompok eksperimen dan kelompok kontrol. Metode Lilliefors digunakan untuk uji normalitas antara kelompok eksperimen dan kelompok kontrol. Metode Bartlett digunakan untuk uji homogenitas antara kelompok eksperimen dan kelompok kontrol.

\section{HASIL DAN PEMBAHASAN}

Data dalam penelitian ini meliputi data hasil uji coba instrumen, data prsetasi belajar matematika, dan data respon belajar matematika. Berikut ini diberikan uraian tentang data-data tersebut:

Dari data prestasi belajar matematika siswa, kemudian ditentukan ukuran tendensi sentralnya yang meliputi mean, tandar deviasi, median, min, max, dan range yang dapat dirangkum dalam tabel berikut ini.

Tabel 2 Deskripsi Data Prestasi Belajar Siswa

\begin{tabular}{lcccc}
\hline METODE & Mean & Min & Max & Range \\
\hline $\begin{array}{l}\text { Kelas } \\
\text { Eksperimen }\end{array}$ & 73.60 & 68.00 & 89.00 & 21.00 \\
\hline $\begin{array}{l}\text { Kelas } \\
\text { Kontrol }\end{array}$ & 63.24 & 55.00 & 81.00 & 26.00 \\
\hline Total & 68.42 & 55.00 & 89.00 & 34.00 \\
\hline
\end{tabular}

Data tentang respon belajar siswa diperoleh dari angket tentang respon belajar siswa, selanjutnya data tersebut dikelompokkan dalam tiga kategori berdasarkan rata-rata gabungan $\left(\bar{X}_{g a b}\right)$ dan standar deviasi gabungan $\left(S_{\text {gab }}\right)$. Dari hasil perhitungan kedua kelompok, diperoleh $\bar{X}_{g a b}=142,68$ dan $\mathrm{S}_{\mathrm{gab}}=10,90$.

Berdasarkan data yang telah terkumpul, dalam kelas eksperimen terdapat 8 siswa yang termasuk kategori respon belajar tinggi, 8 siswa yang termasuk kategori respon belajar sedang dan 9 siswa yang termasuk kategori respon belajar rendah. Sedangkan untuk kelas kontrol terdapat 8 siswa yang termasuk kategori respon belajar tinggi, 10 siswa yang termasuk kategori respon belajar sedang, dan 7 siswa yang termasuk kategori respon belajar rendah.

Tabel 3 Deskripsi Data Respon Belajar Siswa

\begin{tabular}{lcc}
\hline \multirow{2}{*}{ Kategori } & \multicolumn{2}{c}{ Jumlah Siswa } \\
\cline { 2 - 3 } & $\begin{array}{c}\text { Kelas } \\
\text { Eksperimen }\end{array}$ & $\begin{array}{c}\text { Kelas } \\
\text { Kontrol }\end{array}$ \\
\hline Tinggi & 8 & 8 \\
\hline Sedang & 8 & 10 \\
\hline Rendah & 9 & 7 \\
\hline
\end{tabular}

\section{Hasil Pengujian Hipotesis}

Hasil perhitungan analisis variansi dua jalan sel tak sama disajikan pada tabel berikut :

Tabel 4 Rangkuman Analisis Variansi Dua Jalan Dengan Sel Tak Sama

\begin{tabular}{lccc}
\hline & $\mathrm{F}_{\text {obs }}$ & $\mathrm{F}_{\text {tabel }}$ & Keputusan \\
\hline Metode (A) & 43,89 & 4,089 & $\mathrm{H}_{0 \mathrm{~A}}$ ditolak \\
\hline Respon (B) & 8,19 & 3,239 & $\mathrm{H}_{0 \mathrm{~B}}$ ditolak \\
\hline $\begin{array}{l}\text { Interaksi } \\
(\mathrm{AB})\end{array}$ & 2,50 & 3,239 & $\begin{array}{c}\mathrm{H}_{0 \mathrm{AB}} \text { tidak } \\
\text { ditolak }\end{array}$
\end{tabular}

Tabel di atas menunjukkan bahwa :

a. Pada efek utama baris (A) $\mathrm{H}_{0}$ ditolak.

Hal ini berarti terdapat perbedaan perlakuan siswa yang diberi pembelajaran realistik dengan metode penemuan berbantuan interactive multimedia dengan siswa yang diberi perlakuan metode ekspositori terhadap prestasi belajar matematika.

b. Pada efek utama kolom (B) $\mathrm{H}_{0}$ tidak ditolak.

Hal ini berarti terdapat perbedaan prestasi belajar matematika antara siswa dengan respon belajar tinggi, sedang, dan rendah.

c. Pada efek utama interaksi (AB), $\mathrm{H}_{0}$ tidak ditolak. 
Hal ini berarti perbedaan prestasi dari masing-masing metode pembelajaran konsisten pada masing-masing tingkat respon belajar dan tidak adanya perbedaan prestasi belajar dari masing-masing tingkat respon belajar konsisten pada masingmasing metode pembelajaran.

\section{Uji Lanjut Pasca Anava}

Uji lanjut pasca anava dilakukan dengan menggunakan metode Scheffe'. Berdasarkan perhitungan analisis variansi dua jalan sel tak sama telah diperoleh keputusan uji bahwa $\mathrm{H}_{0 \mathrm{~A}}$ ditolak, $\mathrm{H}_{0 \mathrm{~B}}$ ditolak, dan $\mathrm{H}_{0 \mathrm{AB}}$ tidak ditolak.

Pada anava dua jalan sel tak sama ternyata diperoleh keputusan uji bahwa $\mathrm{H}_{0 \mathrm{~A}}$ ditolak. $\mathrm{H}_{0 \mathrm{~A}}$ ditolak dan karena hanya ada dua pembanding maka tidak perlu dilakukan uji komparasi rataan antar baris. Untuk mengetahui mana yang terbaik cukup melihat dari reratanya saja. Diperoleh pembelajaran realistik dengan metode penemuan berbantuan interactive multimedia menghasilkan prestasi belajar yang lebih baik daripada pembelajaran konvensional.

Uji komparasi ganda antar kolom perlu dilakukan karena dari anava dua jalan sel tak sama diperoleh bahwa $\mathrm{H}_{0 \mathrm{~B}}$ ditolak. Dari hasil uji komparasi ganda diperoleh bahwa siswa dengan respon tinggi prestasi belajarnya lebih baik daripada siswa dengan respon rendah, siswa dengan respon tinggi prestasi belajarnya tidak lebih baik daripada siswa dengan respon sedang, dan siswa dengan respon sedang prestasi belajarnya tidak lebih baik daripada siswa dengan respon rendah.

Dari anava dua jalan dengan frekuensi sel tak sama diperoleh $\mathrm{H}_{0 \mathrm{AB}}$ tidak ditolak ini berarti perbedaan prestasi dari masing-masing metode pembelajaran konsisten pada masing-masing tingkat respon belajar dan tidak adanya perbedaan prestasi belajar dari masing-masing tingkat respon belajar konsisten pada masingmasing metode pembelajaran. Karena $\mathrm{H}_{0 \mathrm{AB}}$ tidak ditolak maka tidak perlu diadakan uji komparasi rerata antar sel pada baris yang sama atau pada kolom yang sama.

\section{Pembahasan Hasil Analisis Data}

Berdasarkan hasil perhitungan pada analisis variansi dua jalan dengan sel tak sama diperoleh $\mathrm{F}_{\mathrm{obs}}>\mathrm{F}_{\text {tabel }}$, sehingga $\mathrm{F}_{\text {obs }} \in$ daerah kritik maka $\mathrm{H}_{0 \mathrm{~A}}$ ditolak. Hal ini berarti terdapat perbedaan prestasi belajar antara siswa yang diberi perlakuan pembelajaran realistik dengan metode penemuan berbantuan interactive multimedia dan siswa yang diberi perlakuan metode ekspositori. Dari rataan marginal menunjukkan bahwa secara signifikan rata-rata kelas yang menggunakan pembelajaran realistik dengan metode penemuan berbantuan interactive multimedia lebih besar dari rata-rata kelas yang menggunakan metode ekspositori.

Hal ini disebabkan karena pembelajaran realistik dengan metode penemuan berbantuan interactive multimedia dapat mengaktifkan siswa sehingga proses belajar mengajar dapat menjadi lebih berkualitas. Dikatakan berkualitas karena dalam metode peta konsep dibutuhkan pengertian, pemahaman akan suatu persoalan matematika, pengembangan intelektual, pengembangan sikap-sikap mental, dan kreativitas siswa dalam mengaitkan informasi baru dengan konsep-konsep yang sesuai dengan apa yang telah dimilikinya. Pembelajaran realistik dengan metode penemuan berbantuan interactive multimedia dimulai 
dari urutan yang sederhana menuju pada hal-hal yang lebih kompleks. Suatu konsep dari materi prasyarat harus diajarkan lebih dahulu, apabila konsep tersebut akan diperlukan pada pengajaran materi berikutnya. Sehingga menghasilkan nilai rata-rata siswa lebih tinggi daripada nilai rata-rata siswa yang diajarkan dengan metode ekspositori.

Berdasarkan hasil perhitungan pada analisis variansi dua jalan dengan sel tak sama diperoleh $\mathrm{F}_{\text {obs }}>\mathrm{F}_{\text {tabel, }}$, sehingga $\mathrm{F}_{\mathrm{obs}} \in$ daerah kritik maka $\mathrm{H}_{0 \mathrm{~B}}$ ditolak. Hal ini berarti masing-masing tingkat respon belajar matematika siswa memberikan pengaruh yang berbeda terhadap prestasi belajar matematika.

Setelah dilakukan uji Scheffe' dapat disimpulkan bahwa siswa yang memilki respon belajar matematika tinggi prestasi belajarnya berbeda dengan siswa yang memiliki respon belajar matematika rendah. Dari rataan marginalnya menunjukkan bahwa siswa yang memilki respon belajar tinggi prestasi belajarnya lebih baik dibandingkan siswa yang memilki respon belajar rendah.

Siswa yang memilki respon belajar matematika sedang prestasi belajarnya berbeda dengan siswa yang memiliki respon belajar matematika rendah. Dari rataan marginalnya menunjukkan bahwa siswa yang memilki respon belajar sedang prestasi belajarnya lebih baik dibandingkan siswa yang memilki respon belajar rendah.

Sedangkan siswa yang memilki respon belajar matematika tinggi prestasi belajarnya berbeda dengan siswa yang memiliki respon belajar sedang. Dari rataan marginalnya menunjukkan bahwa siswa yang memilki respon belajar tinggi prestasi belajarnya lebih baik dibandingkan siswa yang memilki respon belajar sedang.
Berdasarkan hasil perhitungan pada analisis variansi dua jalan dengan sel tak sama diperoleh $\mathrm{F}_{\mathrm{obs}}<\mathrm{F}_{\text {tabel }}$, sehingga $\mathrm{F}_{\text {obs }} \notin$ daerah kritik maka $\mathrm{H}_{0 \mathrm{AB}}$ tidak ditolak. Hal ini berarti tidak terdapat interaksi antara metode pembelajaran dan respon belajar siswa terhadap prestasi belajar matematika, artinya metode peta konsep lebih baik daripada metode ekspositori untuk respon belajar tinggi, sedang, maupun rendah. Sebaliknya respon belajar tinggi, sedang, maupun rendah menghasilkan prestasi belajar yang sama, baik pada metode peta konsep dan metode ekspositori.

Tidak ditolaknya $\mathrm{H}_{0 \mathrm{AB}}$ dikarenakan pada saat proses pembelajaran berlangsung, ada sebagian siswa yang tidak memperhatikan pelajaran yang disampaikan oleh guru sehingga mengganggu teman lain yang ingin berkonsentrasi pada pelajaran dan siswa kurang bersungguh-sungguh maupun kurang serius dalam mengisi angket respon belajar matematika.

\section{KESIMPULAN DAN SARAN}

Kesimpulan dari penelitian ini adalah (1) terdapat perbedaan pembelajaran realistik dengan metode penemuan berbantuan interactive multimedia dengan metode ekspositori terhadap prestasi belajar matematika siswa. (2) Terdapat perbedaan prestasi belajar matematika antara siswa dengan respon belajar tinggi, sedang, maupun rendah. (3) Tidak terdapat interaksi antara metode pembelajaran dan respon belajar siswa terhadap prestasi belajar matematika siswa, artinya pembelajaran realistik dengan metode penemuan berbantuan interactive multimedia lebih baik daripada metode ekspositori untuk respon belajar tinggi, sedang, maupun rendah. Sebaliknya respon belajar tinggi, sedang, maupun rendah baik untuk 
pembelajaran realistik dengan metode penemuan berbantuan interactive multimedia dan metode ekspositori.

Saran dalam penelitian ini ditujukan pada guru, calon guru, dan peneliti, yaitu (1) Kepada guru matematika penulis menyarankan agar pembelajaran dengan menggunakan pembelajaran realistik dengan metode penemuan berbantuan interactive multimedia sebagai alternatif dalam usaha meningkatkan prestasi belajar siswa. (2) Dalam penelitian ini metode pembelajaran ditinjau dari respon siswa. Bagi para calon peneliti yang lain mungkin dapat melakukan tinjauan yang lain, misalnya motivasi, karakteristik cara berpikir, gaya belajar, minat siswa, dan lain-lain. (3) Hasil penelitian ini hanya terbatas pada pokok bahasan garis tinggi pada segitiga, sehingga mungkin bisa dicoba diterapkan pada pokok bahasan yang lain dengan mempertimbangkan kesesuaiannya.

\section{DAFTAR PUSTAKA}

Budiyono. 2003. Metodologi Penelitian Pendidikan. Surakarta: UNS Press. 2004. Statistika Dasar Untuk Penelitian. Surakarta: UNS Press.

Ditjet MPDM Depdiknas. 2008. Panduan Pengembangan Multimedia Pembelajaran, Jakarta: Depdiknas.

Jaka Purnama. 2004. Pengaruh Pembelajaran Realistik Terhadap Prestasi Belajar Matematika Pokok Bahasan Geometri Ditinjau Dari Motivasi Melanjutkan Ke Perguruan Tinggi. Tesis. Surakarta:Pasca sarjana UNS
Joko Bekti Haryono. 2005. Pembelajaran Matematika Realistik Pokok Bahasan Relasi dan Pemetaan pada Si.swa Kelas II SMP Negeri Di Sukoharjo. Tesis. Surakarta: Pasca Sarjana UNS

Makmur Sugeng. 2004. Pengaruh Pembelajaran Realistik Terhadap Prestasi Belajar Matemalika Unit Geometri Ditinjau dari Respon Siswa Terhadap Proses Pembelajaran pada Siswa Kela.s III IPA SMU Negeri Kota Surakarta. Tesis. Surakarta: Pasca Sarjana UNS

Marpaung. 2003. Pendidikan Matematika Realistik Indonesia (PMRI) Suatu Alternatif untuk Memperbaiki dan Meningkatkan Kualitas Pendidikan Matematika di Indonesia. 1-6.

Ngalim Purwanto. 2006. Psikologi Pendidikan. Bandung: PT Remaja Rosdakarya.

Oemar Hamalik. 2003. Perencanaan Pengajaran Berdasarkan Pendekatan Sistem, cetakan kedua. Jakarta: PT. Bumi Aksara.

Smaldino. 2011. Intructional Technologi and Media For Learning : Teknologi Pembelajaran dan Media Untuk Belajar. Jakarta: Kencana Prenada Media Group

Sucipto. 2010. Penulisan Naskah Pembelajaran Multimedia Interaktif Berbantuan Komputer (Multimedia). Makalah. Yogyakarta: Balai Teknologi Komunikasi Pendidikan (BTKP) 
72 Jurnal Ilmiah Pendidikan Matematika, Vol. 5 No. 2, Maret 2017 hlm 65-72

Suharsimi Arikunto. 2002. Prosedur

Penelitian, Suatu Pendekatan

Praktek, Edisi Revisi V. Jakarta:

PT. Rineka Cipta 